\title{
Żywność wysokoprzetworzona i jej wpływ na zdrowie dzieci i osób dorosłych
}

\section{STRESZCZENIE}

$\mathrm{O}$ tatnie lata uwidoczniły wyraźny trend zdrowego odżywiania. Pomimo dostępności szeregu produktów naturalnych, na rynku występuje mnóstwo żywności wysokoprzetworzonej. Zasadne wydaje się zatem edukowanie społeczeństwa w kontekście rozsądnego konsumpcjonizmu. Celem pracy, był przegląd literatury w zakresie podziału, sposobu działania oraz wpływu najczęściej stosowanych dodatków do żywności na stan zdrowia dzieci i osób dorosłych. Według IŻŻ stan zdrowego odżywienia organizmu można osiagnaćć poprzez stosowanie się do zasad zawartych w piramidzie zdrowego żywienia i aktywności fizycznej. Niestety, nawyki żywieniowe zarówno osób dorosłych jak i dzieci odbiegają znacząco od przedstawionych w piramidzie zaleceń. Dodatki do żywności stanowią istotny element procesu wytwórczego, który wzbudza wiele kontrowersji. Dzielą się one m.in. na barwniki, konserwanty (substancje konserwujące) czy przeciwutleniacze. Wymienione substancje mogą kumulować się w organizmie i wywierać na niego negatywne skutki zdrowotne. Przedstawiony przegląd literatury wskazuje na konieczność podjęcia działań profilaktycznych oraz edukacji w zakresie zasad prawidłowego żywienia oraz zagrożeń wynikających ze spożywania żywności wysokoprzetworzonej.

\section{WSTĘP}

W ostatnich latach coraz więcej uwagi poświęca się prawidłowemu odżywianiu. Nadeszła „,nowa era” mody na żywność. Z jednej strony zwiększyło się zainteresowanie produktami naturalnymi, pochodzenia ekologicznego, wyprodukowanymi w tradycyjny sposób; z drugiej zaś ogromną część rynku spożywczego nadal zajmuje żywność wysokoprzetworzona, aromatyzowana, kolorowa, o długim terminie przydatności do spożycia.

Ostatnie lata wskazują, że istnieje potrzeba uświadamiania społeczeństwa w kontekście jakości i bezpieczeństwa żywności oraz rozsądnego konsumpcjoni$\mathrm{zmu}$. Tylko prawidłowo skomponowana dieta, bogata $\mathrm{w}$ produkty naturalne, pozbawiona żywności wysokoprzetworzonej (obfitującej w sztuczne dodatki) może wpisać się w element zdrowego stylu życia [1-4].

Celem pracy był przegląd literatury w zakresie podziału, sposobu działania oraz wpływu najczęściej stosowanych dodatków do żywności na stan zdrowia dzieci i osób dorosłych.

\section{PRAWIDŁOWY SPOSÓB ŻYWIENIA WG IŻŻ I WHO}

Zgodnie z wytycznymi Instytutu Żywności i Żywienia (IŻŻ) [5] prawidłowy stan odżywienia organizmu jest możliwy do osiągnięcia dzięki przestrzeganiu zasad zawartych w piramidzie zdrowego żywienia i aktywności fizycznej. Spośród produktów żywnościowych, u podstawy piramidy znalazły się warzywa i owoce, które są źródłem cennych witamin, składników mineralnych i polifenoli. Ich spożycie powinno wynosić min. połowę spośród wszystkich spożywanych w ciągu dnia produktów. Kolejne piętro piramidy zajmują zbożowe produkty pełnoziarniste, a następne nabiał ( $\mathrm{w}$ ilości min. 2 szklanek, np. jogurtu naturalnego). Twórcy piramidy zwrócili także uwagę na konieczność ograniczenia spożycia mięsa (zwłaszcza czerwonego i przetworzonego) i zastąpienie go jajami, nasionami roślin strączkowych oraz rybami. W piramidzie uwzględniono także zalecenia dotyczące ograniczenia spożycia tłuszczów pochodzenia zwierzęcego na rzecz olei roślinnych oraz orzechów, a także ograniczenie spożycia cukrów prostych oraz soli/sodu. Wytyczne te tożsame są z zaleceniami zbilansowanej diety promowanymi przez Światową Organizację Zdrowia (WHO). WHO w celu zapobiegania rozwojowi chorób niezakaźnych (tj. nowotwory, cukrzyca, choroby serca) zaleca ograniczenie spożycia nasyconych kwasów łłuszczowych (NKT) do 10\%, a kwasów tłuszczowych o konfiguracji trans do 1\% dziennego zapotrzebowania energetycznego. Z kolei zalecenia dotyczące spożycia soli, obej- mgr Patrycja Kapczuk ${ }^{\natural}$,

mgr Natalia Komorniak ${ }^{2}$, mgr Karolina Rogulska ${ }^{3}$,

\section{student Mateusz Bosiacki ${ }^{4}$,}

\author{
prof. dr hab. n. med. Dariusz \\ Chlubek $^{1}$
}

${ }^{1}$ Zakład Biochemii, Pomorski Uniwersytet Medyczny w Szczecinie

${ }^{2}$ Katedra i Zakład Żywienia Człowieka i Metabolomiki, Pomorski Uniwersytet Medyczny w Szczecinie

${ }^{3}$ Katedra Mikrobiologii, Immunologii i Medycyny Laboratoryjnej, Pomorski Uniwersytet Medyczny w Szczecinie

${ }^{4}$ Katedra i Zakład Diagnostyki Funkcjonalnej i Medycyny Fizykalnej, Pomorski Uniwersytet

Medyczny w Szczecinie

https://doi.org/10.18388/pb.2020_309

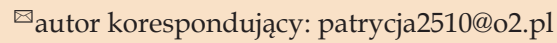

Słowa kluczowe: żywność wysokoprzetworzona, odżywianie, substancje dodatkowe, zdrowie

Wykaz skrótów: ADHD - Zespół nadpobudliwości psychoruchowej z deficytem uwagi (ang. attention deficit hyperactivity disorder); ADI - dopuszczalne dzienne spożycie (ang. acceptable daily intake); BHT - butylohydroksytoluen (ang. dibutylhydroxytoluene); EDTA - kwas wersenowy (ang. ethylenediaminetetraacetic acid); INS - międzynarodowy system numeracji dodatków do żywności (ang. International Numbering System for Food Additives); IZZŻ - Instytut Żywności i Żywienia (ang. National Food and Nutrition Institute); MSG - glutaminian sodu (ang. monosodium glutamate); NKT - nasycone kwasy tłuszczowe (ang. saturated fatty acids); WHO - Światowa Organizacja Zdrowia (ang. World Health Organization); WHR - wskaźnik talia-biodra (ang. waist-hip ratio). 


\section{PIRAMIDA ZDROWEGO ŻYWIENIA}

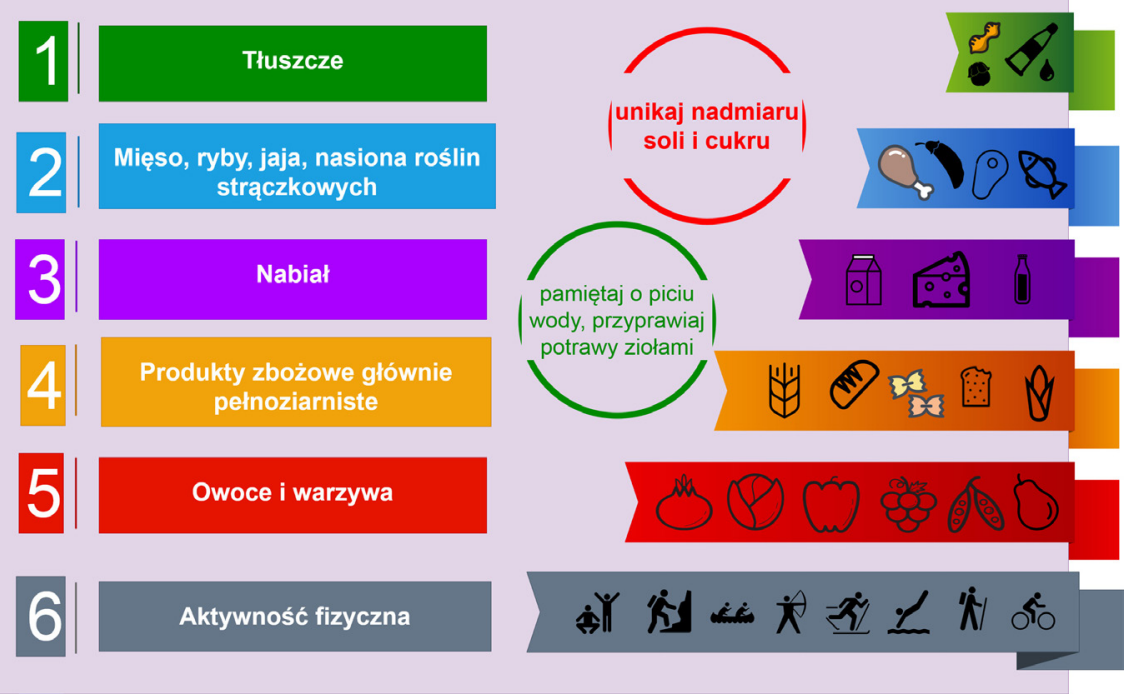

Rycina 1. Piramida żywienia zgodnie z najnowszymi wytycznymi Instytutu Żywności i Żywienia.

mują jej ograniczenie do $5 \mathrm{~g} /$ dzień, a cukrów prostych do $10 \%$, a nawet $5 \%$ dziennego zapotrzebowania energetycznego. Aby wytyczne te były możliwe do spełnienia, WHO wskazuje na konieczność ograniczenia spożycia żywności wysokoprzetworzonej, która obfituje w NKT, sól, cukier oraz liczne dodatki (tj. konserwanty, sztuczne barwniki) [6] (Ryc. 1).

\section{NAWYKI ŻYWIENIOWE DZIECI I DOROSŁYCH}

Przeprowadzone w ostatnich latach badania wskazują, że sposób odżywiania się zarówno dzieci, jak i osób dorosłych różni się od przedstawionych powyżej wytycznych. Szacuje się zwiększoną liczbę zgonów oraz większy wzrost zachorowalności na przewlekłe schorzenia wynikające ze złego odżywania w Polsce w porównaniu z innymi krajami europejskimi o podobnym statusie socjo-ekonomicznym $[2,7]$. W artykule opublikowanym w Developmental Period Medicine [8] wykazano, że do najpopularniejszych produktów spożywanych przez badane dzieci i młodzież (między 1 a 18 rokiem życia) należały frytki $(27 \%)$, czekolada $(27 \%)$ oraz pizza $(23 \%)$. Wykazano także, że chłopcy preferują żywność przygotowywaną na bazie oleju palmowego oraz zawierającą butylohydroksytoluen (BHT), a dziewczynki częściej sięgają po produkty zawierające w składzie jaja. Praca ujawniła także, bardzo niepokojącą ujemną korelację pomiędzy wiekiem badanych dzieci a spożyciem produktów zawierających syrop cukrowy, glukozowy oraz glukozowo-fruktozowy, których spożycie zwiększa ryzyko rozwoju otyłości oraz cukrzycy typu 2 [9]. Do głównych potencjalnie niebezpiecznych (zważywszy na wiek badanych dzieci) dodatków spożywanych wraz z żywnością należały: salicylany, glutaminian sodu, benzoesan sodu i sorbinian potasu, siarczan żelaza i siarczan amonu, BHT oraz sól wapniowo-disodowa EDTA [8]. Także w innym badaniu [10] przeprowadzonym wśród osób w wieku 13-15 lat wykazano, że młodzież chętnie sięga po produkty wysokoprzetworzone. Przekąski typu fast-food i słodzone napoje gazowane pojawiały się w racji pokarmowej respondentów kilka razy w tygodniu (33\%) oraz kilka razy w miesiącu (60\%). Z kolei słodzone napoje gazowane (w ilości 11/dobę) były spożywane przez aż $70 \%$ osób.

W badaniu [11] skupiającym się na nawykach żywieniowych osób dorosłych wykazano, że wraz z wiekiem zmniejszała się częstość spożycia mleka, ryżu brązowego, makaronu razowego oraz płatków owsianych. Zwiększało się natomiast spożycie soli, kawy oraz podrobów. Te niekorzystne tendencje znalazły odzwierciedlenie w pomiarach antropometrycznych. Wykazano bowiem, że wraz z wiekiem zwiększeniu ulegał wskaźnik masy ciała oraz procentowa zawartość tkanki tłuszczowej. Zgodnie z danymi WHO [12], otyłość dotyczy aż $650 \mathrm{mln}$ osób dorosłych oraz 340 mln dzieci i młodzieży na świecie. Statystyki te są o tyle niepokojące, że także wśród pacjentów z otyłością olbrzymią, pomimo tego, iż przygotowują się oni do operacji bariatrycznej, odnotowywane są liczne błędy żywieniowe. Wykazano, że wraz ze wzrostem wskaźnika talia biodra (WHR) wśród tych osób zwiększała się częstotliwość spożycia tłuszczów zwierzęcych (smalcu, słoniny) oraz napojów energetycznych i piwa. Jednocześnie zwiększało się także spożycie lodów i budyniu, twarożków smakowych oraz kiełbas, które są źródłem m.in. NKT, soli oraz sztucznych barwników i konserwantów [13].

\section{PODZIAŁ DODATKÓW DO ŻYWNOŚCI}

Dodatki do żywności oraz ich podział ze względu na zastosowanie technologiczne jest dość obszernym zagadnieniem, który dotyczy m.in.: Food constient, Food ingredient i Food additive. Food constient oznacza dodatek występujący w pierwotnym składzie danego produktu; Food ingredient określa substancję, która w momencie dodania do produktu staje się jego składową. Natomiast Food additive oznacza związek dodawany do żywności, w celu poprawienia walorów smakowych, zapachowych, przedłużających jego trwałość oraz zmniejszających jego koszty produkcji. Substancja ta przeważnie nie jest stosowana jako samodzielny produkt 


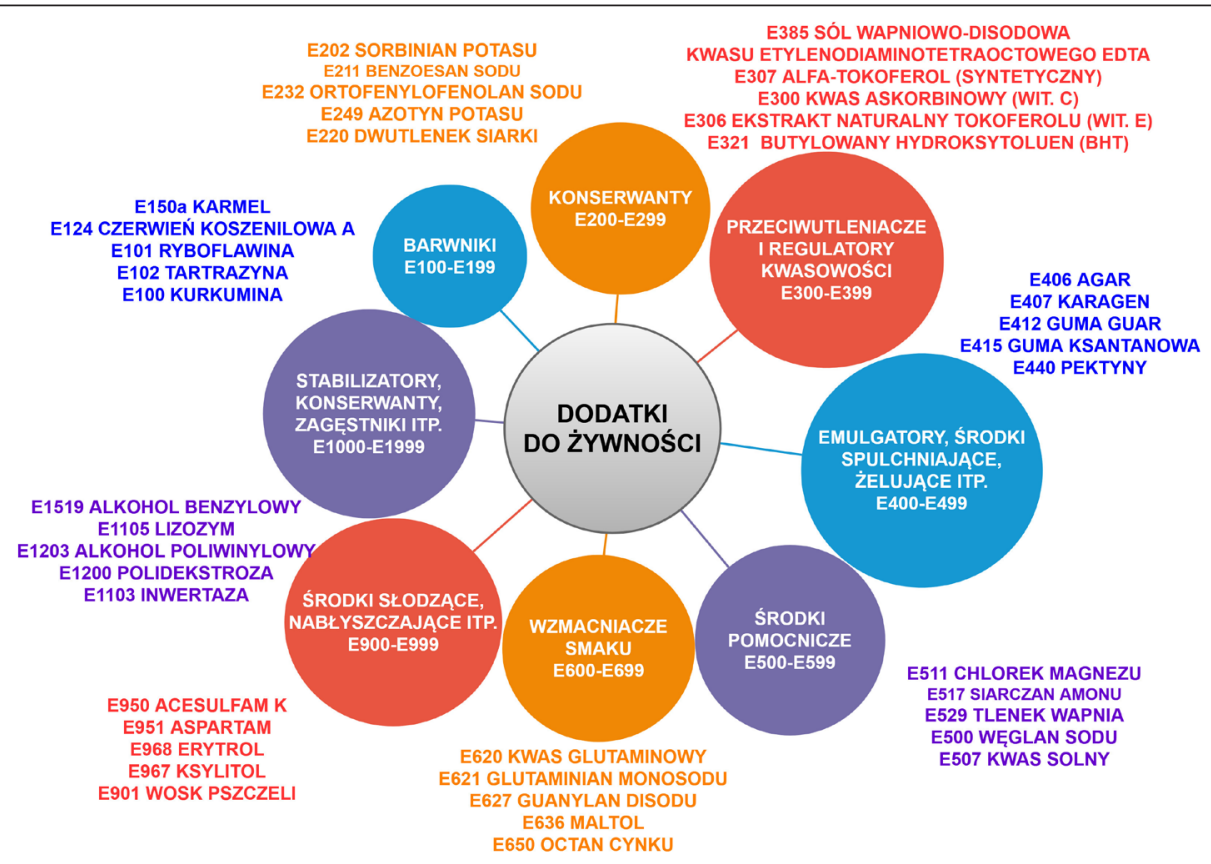

Rycina 2. Najczęściej stosowane dodatki do żywności zgodnie z międzynarodowym systemem identyfikacyjnym INS.

spożywczy, nie jest również typowym składnikiem żywności. $Z$ reguły nie posiada żadnych wartości odżywczych. Z punktu widzenia producenta pomaga w czasie produkcji, przetwarzania, preparowania, transportu, a co za tym idzie obniża jego koszty.

W krajach europejskich, producentów żywności obowiązuje prawo dotyczące zawartości w żywności poszczególnych substancji określanych jako konserwanty i przeciwutleniacze. W Polsce informacje dotyczące stosowania różnych rodzajów substancji utrwalających do żywności odnaleźć można w zarządzeniach Ministerstwa Zdrowia oraz w ustawie z dnia 25 sierpnia 2006 roku „O bezpieczeństwie żywności i żywienia". Dodatkowo Komitet Ekspertów powołany przez WHO/FAO, ds. dodatków do żywności wprowadził pojęcie dopuszczalnego dziennego spożycia dodatku do żywności (ADI, ang. acceptable daily intake). Wartość ta określa ilość danej substancji (wyrażonej na kilogram masy ciała na dobę), która może zostać spożyta nie powodując ryzyka zagrożenia zdrowia. Oprócz tego piecze nad jakością „zdrowej” żywności sprawuje Komisja Kodeksu Żywnościowego przy WHO oraz Organizacja ds. Żywności i Rolnictwa [14-18].

Ze względu na funkcje technologiczne dodatki do żywności dzieli się na: konserwanty (substancje konserwujące); przeciwutleniacze; barwniki; emulgatory; substancje: słodzące, przeciwpieniące, przeciwzbrylające, wypełniające, zagęszczające, wiążące, pianotwórcze, utrzymujące wilgoć, spulchniające, żelujące oraz glazurujące; regulatory kwasowości; stabilizatory; wzmacniacze smaku; nośniki; skrobie modyfikowane; wzmacniacze kontrastu; polepszacze oraz gazy do pakowania i gazy nośne (Ryc. 2).

Analizując rodzaje dodatków w technologii żywności należy wspomnieć o międzynarodowym systemie identyfikacyjnym INS (ang. International Numbering System for Food
Tabela 1. Tabela przedstawiająca poszczególne grupy dodatków do żywności i odpowiadające im numery zgodnie z międzynarodowym systemem identyfikacyjnym INS.

\begin{tabular}{|ll}
\hline Numer & Rodzaj dodatku \\
\hline 100-199 & barwniki \\
\hline 200-299 & konserwanty \\
\hline 300-399 & przeciwutleniacze i regulator kwasowości \\
\hline $400-499$ & emulgatory, środki spulchniające, żelujące itd. \\
\hline $500-599$ & środki pomocnicze \\
\hline $600-699$ & wzmacniacze smaku \\
\hline $900-999$ & środki słodzące, nabłyszczające i inne \\
\hline $1000-1999$ & stabilizatory, konserwanty, zagęstniki i inne \\
\hline
\end{tabular}

Additives). Kod ten rozpoczyna się symbolem „E" oraz zawiera odpowiednią numerację. INS obowiązuje w całej Europie i dotyczy wszystkich producentów (Tabela 1).

\section{BARWNIKI}

Barwniki będące pierwszą grupą dodatków do żywności stanowią szeroką gamę substancji zarówno pochodzenia naturalnego jak i sztucznego. Do najlepiej poznanych barwników występujących w produktach spożywczych zaliczana jest tartrazyna (żółcień spożywcza). Używana jest najczęściej do produkcji leków jako barwnik kapsułek i tabletek. Wykazano, że może powodować reakcje alergiczne: świąd warg i języka, stany zapalne, bezsenność, stany depresyjne, nietolerancję niesterydowych leków przeciwzapalnych, a nawet anafilaksję. Ponadto sugeruje się, że w połączeniu z benzoesanami może wywołać zespół nadpobudliwości psychoruchowej z deficytem uwagi (ADHD, ang. attention-deficit hyperactivity disorder) u dzieci [1,19]. 


\section{SUBSTANCJE KONSERWUJĄCE}

Substancje konserwujące stosowane są w żywności, aby zapobiegać powstawaniu niekorzystnych cech produktu, zachodzących na skutek procesów mikrobiologicznych (np. pleśnienie), enzymatycznych (np. enzymatyczne brunatnienie), chemicznych (np. nieenzymatyczne brunatnienie) oraz fizycznych (np. zbrylanie). Cechą charakterystyczną tych substancji jest ich niezawodne działanie, które nie zmienia naturalnych cech produktów oraz nie powinno mieć niekorzystnego wpływu na zdrowie człowieka. Związki te, nie mają szerokiego spektrum działania na wszystkie mikroorganizmy, dlatego w celu zahamowania fizjologicznych procesów związanych z ich wzrostem często stosuje się kilka rodzajów konserwantów. Procedura ta przyczynia się do zwiększenia bezpieczeństwa żywności, ale może być także przyczyną wywołania reakcji nadwrażliwości na użyte dodatki bądź zwiększać prawdopodobieństwo wystąpienia reakcji krzyżowych. Aby zapobiec nadmiernemu spożyciu substancji dodatkowych należy przestrzegać bezpiecznej dopuszczalnej normy dziennego spożycia, które zostało ustalone dla każdej substancji dodatkowej. [20-24].

Z badań wynika, że pomimo restrykcji związanych z zastosowaniem konserwantów do żywności, obserwuje się wzmożone reakcje nadwrażliwości u osób chorujących na astmę oskrzelową, z alergicznym nieżytem nosa oraz u osób ze skórnymi alergiami, które spożywały produkty $\mathrm{z}$ dodatkiem konserwantu $\mathrm{w}$ postaci kwasu benzoesowego. Natomiast wyniki badań, w których wykorzystano jako model badawczy zwierzęta, wykazały potencjalne, negatywne działanie benzoesanu na mięśnie powodując ich osłabienie oraz uszkodzenia gałek ocznych u potomstwa szczurów narażonych na benzoesan sodu [1]. W badaniu przeprowadzonym na myszach wykazano, że nawet krótkotrwałe spożywanie benzoesanu sodu może upośledzać pamięć oraz zwiększać stres oksydacyjny w obrębie mózgu [25]. Zaobserwowano również, że ekspozycja na siarczyny należące do grupy konserwantów, może powodować zaostrzenie alergii u ludzi (świąd, obrzęki, pokrzywki), reakcje niepożądane ze strony układu pokarmowego w postaci nudności, wymiotów, biegunek, bólu brzucha oraz trudności w przełykaniu. U osób z niedoborem enzymu oksydazy siarczynowej stwierdza się nieprawidłową tolerancję siarczynów w pożywieniu wywołując bóle głowy, omdlenia, zmiany temperatury ciała oraz tętna. Ponadto opisano przypadek nawracającego ciężkiego niedociśnienia i anafilaksji po spożyciu siarczynów u mężczyzny w średnim wieku $[19,26]$.

\section{PRZECIWUTLENIACZE}

Kolejną grupę środków, wykorzystywanych w celu przedłużenia trwałości produktów żywnościowych stanowią przeciwutleniacze. W stosunku do konserwantów charakteryzują się one innym mechanizmem działania. Przeciwutleniacze mają za zadanie ograniczyć działanie tlenu, a w konsekwencji zapobiec utlenianiu składników żywności. Ochrona przed wpływem tlenu zachodzi głównie w oparciu o: wstrzymanie biologicznego utleniania substancji tlenem $z$ powietrza (te substancje, które nie są pochodzenia tłuszczowego) z wykorzystaniem enzymów oraz chemicz- nego utleniania tłuszczów (jełczenia). Zapobieganie procesom utleniania żywności polega na hamowaniu szybkości reakcji utleniania [27]. Do grupy przeciwutleniaczy zaliczane są także naturalne antyoksydanty - tokoferole. Są one pozyskiwane z łusek oraz olei roślinnych. Z klinicznego punktu widzenia, ekspozycja na tę grupę dodatków do żywości może skutkować objawami ze strony przewodu pokarmowego zwłaszcza u dzieci. Zauważono przypadki reakcji alergicznych na lecytynę sojową u piekarzy, której przypisuje się zaostrzenie astmy oskrzelowej (choroby zawodowej) [28].

\section{EMULGATORY, ŚRODKI SPULCHNIAJĄCE, ŻELUJĄCE}

Emulgatory, środki spulchniające, żelujące, itd. wykorzystywane są głównie w celu stabilizacji produktu spożywczego. Wg danych literaturowych działania uboczne po ekspozycji na tę grupę występują sporadycznie. Obserwuje się łagodne reakcje alergiczne ze strony układu pokarmowego. Należy jednak zwrócić uwagę na przypadki reakcji niepożądanych na mączkę chleba świętojańskiego zwaną inaczej gumą karobową. W przypadku tego dodatku stwierdzono występowanie obrzęku naczynioruchowego u dzieci jak i u dorosłych w wyniku kontaktu inhalacyjnego oraz po spożyciu [29].

\section{ŚRODKI POMOCNICZE}

Rozważając temat żywności wysokoprzetworzonej należy wspomnieć także o grupie dodatków w postaci środków pomocniczych. Do tej pory nie stwierdzono dużej liczby przypadków negatywnego wpływu tych substancji na organizm ludzki. W literaturze, opisywany jest potencjalny wpływ węglanu sodu (często wykorzystywanego regulatora kwasowości) na układ oddechowy (duszności) oraz na występowanie reakcji alergicznych (pokrzywka) [1].

Zupełnie inaczej wygląda sytuacja w przypadku glutaminianu sodu (MSG, ang. monosodium glutamate) - jednego z najczęściej stosowanych wzmacniaczy smaku. Obecnie jest on powszechnie wykorzystywany do produkcji, m.in. kostek rosołowych, produktów typu instant, sosów, zup w proszku, a nawet keczupu, przez co istnieje ryzyko jego wysokiego spożycia w społeczeństwie. Badania wskazują, że jest on uznawany za przyczynę rozwoju "zespołu chińskiej restauracji" charakteryzującego się licznymi objawami, tj. ból głowy, zaczerwienienie, pocenie się, uczucie ucisku w jamie ustnej lub głowie, kołatanie serca, a nawet chwilowy paraliż [30]. Dodatkowo wskazuje się na jego różnorodne działanie toksyczne, obejmujące powiązania z rozwojem otyłości i zaburzeń metabolicznych (np. zwiększone stężenie leptyny, interleukiny 6, insuliny, nieprawidłowa tolerancja glukozy), a nawet szkodliwym wpływem na układ rozrodczy (np. stres oksydacyjny, uszkodzenie DNA, hipertrofia komórkowa osłonki pęcherzyka jajnikowego) i neurotoksyczność (np. niepokój, demencja) [31]. Spożywanie MSG może wywierać wpływ na przekaźnictwo nerwowe w związku z mechanizmem interferencji z kwasem glutaminowym jako neuroprzekaźnikiem. Stwierdzono także zależność pomiędzy zwiększonym występowaniem nadpobudliwości u dzieci a spożywaniem MSG [32]. 


\section{CUKIER, ŚRODKI SŁODZĄCE, NABEYSZCZAJĄCE I INNE}

W obliczu światowego kryzysu otyłości, liczne dowody naukowe wskazują, że jedną z przyczyn jej występowania jest rosnące spożycie cukru [33]. Mowa tu zarówno o sacharozie, tj. cukrze znajdującym się w cukiernicy (białym lub trzcinowym), jak i tym znajdującym się w produktach wysokoprzetworzonych, w postaci, np. dekstrozy, syropu glukozowo-fruktozowego, czy syropu kukurydzianego [34]. W badaniach wykazano, że wysokie spożycie cukru zwiększa ryzyko rozwoju składowych zespołu metabolicznego, cukrzycy typu 2, niealkoholowego stłuszczenia wątroby, próchnicy zębów, dny moczanowej, chorób układu sercowo-naczyniowego oraz nowotworów [35-39]. Wysokie spożycie napojów słodzonych cukrem oraz fruktozą w czasie ciąży i we wczesnym dzieciństwie jest także związane z niezależnym od zawartości tkanki tłuszczowej rozwojem astmy w dzieciństwie [40]. Nie bez znaczenia dla zdrowia człowieka jest także spożycie sztucznych słodzików, które coraz częściej dodawane są przez producentów zarówno do słodkich przekąsek jak i napojów energetycznych. Służą one przede wszystkim zmianie smaku, zapachu oraz przedłużeniu trwałości produktu. Najbardziej popularne z nich używane jako zamiennik cukru to: aspartam, acesulfam-K, sacharynian sodu, ksylitol oraz erytrol. Z uwagi na ich szerokie zastosowanie w produkcji napojów niealkoholowych oraz żywności dietetycznej i o obniżonej kaloryczności skutki ich działania są najlepiej poznane. Dotychczas były one uważane za dodatki skuteczne w walce z otyłością i nadwagą, a także stosowane jako substytut cukru dla diabetyków i dzieci w celu zwalczania próchnicy zębów [41]. Badania sugerują jednak, że stosowanie tej grupy dodatków może mieć szkodliwy wpływ na organizmy ludzi i zwierząt. Słodziki mogą przyczyniać się do rozwoju zespołu metabolicznego oraz epidemii otyłości, poprzez zmiany w obrębie mikrobiomu. Mechanizm obejmuje obniżenie uczucia sytości, zmiany w stężeniu glukozy we krwi oraz zwiększanie spożycia kalorii, co w rezultacie przyczynia się do wzrostu masy ciała [42]. Wykazano także, że spożywanie sztucznie słodzonych napojów bezalkoholowych związane jest z wczesną menarche u dziewczynek [43]. Dodatkowo negatywnym skutkiem spożywania sacharyny jest działanie kancerogenne, które wykazano w badaniach na zwierzętach (szczurach). Natomiast u ludzi zauważono nieliczne przypadki objawów ze strony przewodu pokarmowego, uszkodzenia nerek oraz reakcji nadwrażliwości [44,45]. W przypadku stosowania aspartamu wykazano, iż może on wywoływać takie objawy jak: bóle głowy, napady padaczkowe oraz nagłe zmiany nastroju: od euforii po depresję. Ponadto wykazano, że metabolity aspartamu (fenyloalanina, kwas asparaginowy, metanol) również wywierają negatywny wpływ na organizm ludzki. W szczególności u osób chorych na fenyloketonurię fenyloalanina może działać toksycznie oraz może przyczynić się do nieodwracalnego uszkodzenia mózgu a nawet zgonu $[46,47]$. W przeciwieństwie do aspartamu, acesulfam-K ulega wydaleniu z organizmu w niezmienionej postaci. Jednak dodatek ten może przyczyniać się do uszkodzenia struktury chromosomów, co potwierdzają badania przeprowadzone na modelu mysim. Genotoksyczne działanie acesulfamu-K spowodowało uszkodzenia komórek na zasadzie interakcji tego związku z DNA [48].

\section{STABILIZATORY, ZAGĘSTNIKI I INNE}

Ostatnia grupę tworzą stabilizatory, zagęstniki i inne. Reprezentantem tej grupy, powszechnie używanym w produkcji żywności jest lizozym. Najczęściej stosowany jest do produkcji serów dojrzewających. Cechą charakteryzującą tego dodatku jest gwarancja bezpiecznego spożywania [1].

\section{SÓL}

Substancją występującą w dużej ilości w żywności wysokoprzetworzonej jest także sól. Jej wysokie spożycie zwiększa ryzyko rozwoju chorób układu sercowo-naczyniowego oraz udaru mózgu [49]. Podwyższone stężenie sodu w surowicy krwi jest także niezależnym czynnikiem ryzyka rozwoju przewlekłej niewydolności nerek [50]. Szczególną uwagę na zawartość soli w diecie powinny zwrócić kobiety w ciąży, ponieważ jej wysokie spożycie jest jednym z czynników ryzyka wystąpienia stanu przedrzucawkowego [51].

\section{PODSUMOWANIE}

Przeprowadzony przegląd literatury wskazuje na konieczność podjęcia działań profilaktycznych oraz edukacji zarówno dzieci jak i dorosłych w zakresie zasad prawidłowego żywienia oraz zagrożeń wynikających ze spożywania żywności wysokoprzetworzonej. Duża ilość substancji dodatkowych w wysokoprzetworzoych produktach spożywczych, związana jest z możliwością kumulowania się tych substancji w organizmie i wywierania na niego negatywnych skutków zdrowotnych. Z tego względu szczególną uwagę w planowaniu posiłków powinno zwrócić się w przypadku małych dzieci, osób starszych oraz kobiet w ciąży i karmiących.

\section{PIŚMIENNICTWO}

1. Buczyłko K (2016) Nadwrażliwość na dodatki do żywności. Alergol Pol 3: 95-101

2. Wolski T, Karwat ID, Najda A (2005) Kontaminacja i suplementacja żywności a zdrowie. Post Fitoter 1-2: 35-41

3. Socha D (2012) Nawyki żywieniowe kształtowane przez sklepiki szkolne jako wyraz działań polityki zdrowotnej wobec dzieci. Zdrowie Publiczne i Zarządzanie 10(B): 227-239

4. Niedźwiedzka B, Mazzocchi M, Modugno L, Piórecka B, Kozioł-Kozakowska A, Aschemann-Witzel J, i inni. (2012) Zachowania Informacyjne Polaków dotyczące zdrowego odżywiania. Wyniki badania EATWELL. Zdrowie Publiczne i Zarządzanie 10: 57-64

5. Piramida Zdrowego Żywienia i Aktywności Fizycznej dla osób dorosłych [online]. Narodowe Centrum Edukacji Żywieniowej [przeglądany: 16.03.2020]. Dostępny w: https://ncez.pl/abc-zywienia-/zasady-zdrowego-zywienia/ piramida-zdrowego-zywienia-i-aktywnoscifizycznej-dla-osob-doroslych.

6. Healthy diet [online]. World Health Organization [przeglądany: 16.03.2020]. Dostępny w: https://www.who.int/news-room/fact-sheets/detail/healthy-diet.

7. Kozioł-Kozakowska A, Piórecka B, Schlegel-Zawadzka M (2014) Wpływ postaw rodzicielskich na sposób żywienia dzieci $\mathrm{w}$ wieku przedszkolnym w Krakowie na tle uwarunkowań socjodemograficznych. Zdrowie Publiczne i Zarządzanie 12: 82-89

8. Budrewicz S, Banaszczak M, Piotrowski J, Czerwińska M, Stachowska E (2017) Allergens and food additives, including potentially harmful ones, present in food products that are preferred by children and adolescents. Dev Period Med. 21: 131-138 
9. Patterson ME, Yee JK, Wahjudi P, Mao CS, Lee WP (2018) Acute metabolic response to high fructose corn syrup ingestion in adolescents with overweight/obesity and diabetes. J Nutr Intermed Metab 14: 1-7

10. Wanat G, Grochowska-Niedworok E, Kardas M, Całyniuk B (2011) Nieprawidłowe nawyki żywieniowe i związane z nimi zagrożenie dla zdrowia wśród młodzieży gimnazjalnej. Hygeia Public Health 46: 381-384

11. Adamska E, Ostrowska L, Adamska E, Maliszewska K, Citko A, Waszczeniuk M, et al. (2012) Różnice w nawykach i preferencjach żywieniowych osób dorosłych w zależności od wieku. Rocz Państ Zakł Hig 63: 73-81

12. Obesity and overweight [online]. World Health Organization [przeglądany 16.03.2020]. Dostępny w: https://www.who.int/news-room/fact-sheets/detail/obesity-and-overweight.

13. Komorniak N, Hawryłkowicz V, Dziedzic A, Skonieczna-Żydecka K, Stachowska E, Szczuko S (2019) What are the diets of patients before bariatric surgery? Rocz Państ Zakł Hig 70: 79-87

14. Ratusz K, Maszewska M (2012) Ocena występowania konserwantów w żywności na rynku warszawskim. Bromatol Chem Toksyk 3: 917922

15. Rogozińska I, Wichrowska D (2011) Najpopularniejsze dodatki utrwalające stosowane $\mathrm{w}$ nowoczesnej technologii żywności. Inż. Apar Chem 50: 19-21

16. Rozporządzenie Ministra Zdrowia z dnia 2 sierpnia 2002 w sprawie definicji substancji dodatkowych (Dz. U. Nr 73 poz. 780).

17. Rozporządzenie Ministra Zdrowia z dnia 19 grudnia $2002 \mathrm{w}$ sprawie substancji wzbogacających dodawanych do żywności i warunków ich stosowania (Dz. U. Nr 27 poz. 237).

18. Ustawa z dnia 25 sierpnia 2006 roku o bezpieczeństwie żywności i żywienia. (Dz.U. $2006 \mathrm{nr} 171$ poz. 1225).

19. Wasilewska E, Małgorzewicz S (2015) Niepożądane reakcje pokarmowe na dodatki do żywności. Forum Zab Metab 6: 8-13

20. Szponar L, Gielecińska (2000) Substancje dodatkowe i dodatki funkcjonalne a bezpieczeństwo żywności i jej wartość żywieniowa. Post Fitoter 1: 7-9

21. Rozporządzenie Parlamentu Europejskiego i Rady (WE) z 16 grudnia 2008 w sprawie dodatków do żywności (Dz. U. UE 354 z 31 grudnia 2008, s. 16).

22. Rozporządzenie Ministra Zdrowia z dnia 13 grudnia 2003 w sprawie maksymalnych poziomów zanieczyszczeń chemicznych i biologicznych, które mogą znajdować się w żywności, dodawanych substancjach dodatkowych, substancjach pomagających w przetwarzaniu albo na powierzchni żywności (Dz. U. Nr 37 z dnia 4 marca 2003).

23. Wasilewska E, Małgorzewicz S (2015) Niepożądane reakcje pokarmowe na dodatki do żywności. Forum Zab Metab 6: 8-13

24. Rogozińska I, Wichrowska D (2011) Najpopularniejsze dodatki utrwalające stosowane w nowoczesnej technologii żywności. Inż Ap Chem 50: 19-21

25. Khoshnoud MJ, Siavashpour A, Bakhshizadeh M, Rashedinia M (2018) Effects of sodium benzoate, a commonly udes food preservative on learning, memory and oxidative stress in brain of mice. J Biochem. Mol Toxicol: \#jbt.22022 https:/ / doi.org/10.1002/jbt.22022

26. Cifuentes L, Ring J, Brockow K (2013) Clonal Mast Cell Activation Syndrome with Anaphylaxis to Sulfites. Int Arch Allergy Immunol 162: 94-96

27. Codex Alimentarius General-standard for food additives 2015[online] [przeglądany 16.03.2020]. Dostępny w: http://www.fao.org/ fao-who-codexalimentarius/sh-proxy/en/?lnk $=1 \&$ url=https $\% 253 \mathrm{~A}$ \%252F\% 252Fworkspace.fao.org \% 252Fsites \% 252Fcodex\%252FStandards\%252FCXS\%2B192-1995\%252FCXS_192e.pdf.

28. Pałczyński C, Kuna P (2015) Dodatki do żywności a zdrowie. Rozpuszczalniki, substancje glazurujące, zagęstniki. Alergia 2: 28-32

29. Pałczyński C, Kuna P (2015) Dodatki do żywności a zdrowie. Słodziki, wzmacniacze smaku, emulgatory, stabilizatory. Alergia 1: 39-43

30. D'Mello JPF (2003) Food Safety: Contaminants and Toxins, CABI Publishing, London
31. Niaz K, Zaplatic E, Spoor J (2018) Extensive use of monosodium glutamate: a threat to public health? Excli J 17: 273-278

32. Obayashi O, Nagamura Y (2016) Does monosodium glutamate really cause headache? A systematic review of human studies. J Headache Pain 17: 54

33. Te Morenga L, Mallard S, Mann J (2013) Dietary sugars and body weight: systemic review and meta-analyses of randomized controlled trials and cohort studies. BMJ: \#bmj.e7492 https://doi.org/10.1136/ bmj.e7492

34. Kłosiewicz-Latoszek L, Cybulska B (2011) Cukier a ryzyko otyłości, cukrzycy i chorób sercowo-naczyniowych. Probl Hig Epidemiol 92: 181-186

35. Johnson RJ, Nakagawa T, Sanches-Lozada LG, Shafiu M, Sundaram S, Le M, et al. (2013) Sugar, uric acid and the etiology of diabetes and obesity. Diabetes 62: 3307-3315

36. Stanhope KL, Medici V, Bremer AA, Lee V, Lam HD, Nunez MV, et al. (2015) A dose-response study of consuming high-fructose corn syrup-sweetened beverages on lipid/lipoprotein risk factors for cardiovscular disease in young adults. Am J Clin Nutr 101: 1141-1154

37. Pudło H, Respondek M, Szewczyk-Polowczyk L, Wengel-Woźny K (2015) Wpływ diety na występowanie chorób nowotworowych. J Educ Health Sport 5: 549-558

38. Jegatheesan P, De Bandt JP (2017) Fructose and NAFLD: the multifaceted aspects of fructose metabolism. Nutrients: \#nu9030230 https:/ / doi.org/10.3390 / nu9030230

39. Delli Bovi AP, Di Michele L, Laino G, Vajro P (2017) Obesity and obesity related diseases, sugar consumption and bad oral health: a fatal epidemic mixtures: the pediatric and odontologist point of view. Transl Med UniSa 16: 11-16

40. Wright LS, Rifas-Shiman SL, Oken E, Litonjua AA, Gold DR (2018) Prenatal and early life fructose-containing beverages and mildchildhood asthma. Ann Am Thorac Soc 15: 217-224

41. Sękalska B (2007) Zawartość sztucznych substancji słodzących - aspartamu, acesulfamu-K i sacharynianu sodu $\mathrm{w}$ napojach dietetycznych. Żywn Nauka Technol Jakość 3: 127-138

42. Pearlman M, Obert J, Casey L (2017) The Association Between Artificial Sweeteners and Obesity. Curr Gastroenterol Rep: \#s11894-0170602-9 https:/ / doi.org/10.1007/s11894-017-0602-9.

43. Mueller NT, Jacobs Jr DR, Maclehose RF, Demerath EW, Kelly SP., Dreyfus JG, et al. (2015) Consumption of caffeinated and artificially sweetened soft drinks is associated with risk of early menarche. Am J Clin Nutr 102: 648-54

44. Whysner J, Williams G (1996) Saccharin mechanistic data and risk assessment: urine composition, enhanced cell proliferation and tumor promotion. Pharmacol Ther 71: 225-252

45. Arnold DL (1984) Toxicology of saccharin. Fundam Appl Toxicol. 4: 674-685

46. American Dietetic Association (2004) Position of the American Dietetic Association: Use of Nutritive and nonnutritive sweeteners. J Am Diet Assoc 2: 255-275

47. Wróbel K, Wróbel K(1997) Determination of aspartameand phenyloalanineindietsoftdrinksbyHPLCwithdirectspectrofluorometricdetection. J Chromatogr A 733: 163-168

48. Mukherjee A, Chakrabarti J (1997) In vivo cytogenic studies on mice expose to acesulfame $\mathrm{K}$ - a non-nutrive sweetener. Food Chem Toxicol 35: 1177-1179

49. Strazzullo P, D’Elia L, Kandala NB, Cappuccio FP (2009) Salt intake, stroke and cardiovascular disease: meta-analysis of prospective studies. BMJ: \#bmj.b4567 https:/ / doi.org/10.1136/bmj.b4567

50. Kuwabara M, Hisatome I, Roncal-Jimenez CA, Niwa K, Andres-Hernando A, Jensen T, et al. (2017) Increased serum sodium and serum osmolarity are independent risk factors for developing chronic kidney disease; 5 hear cohort study. Plos One: \# journal.pone.0169137 https://doi.org/10.1371/journal.pone.0169137

51. Birukov A, Andersen LB, Herse F, Rakova N, Kitlen G, Kyhl HB, et al. (2019) Aldosterone, salt and potassium intakes as a predictors of pregnancy outcome, including preeclampsia. Hypertension 74: 391-398 


\section{Highly processed food and its effect on health of children and adults}

\section{Patrycja Kapczuk $^{1 凶}$, Natalia Komorniak ${ }^{2}$, Karolina Rogulska ${ }^{3}$, Mateusz Bosiacki ${ }^{4}$, Dariusz Chlubek ${ }^{1}$}

${ }^{1}$ Department of Biochemistry, Pomeranian Medical University in Szczecin

${ }^{2}$ Department of Human Nutrition and Metabolomics, Pomeranian Medical University in Szczecin

${ }^{3}$ Department of Microbiology, Immunology and Diagnostic Medicine, Pomeranian Medical University in Szczecin

${ }^{4}$ Chair and Department of Functional Diagnostics and Physical Medicine, Pomeranian Medical University in Szczecin

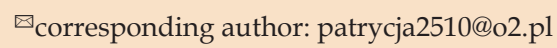

Key words: highly processed food, nutrition, additives, health

\section{SUMMARY}

Despite the availability of a number of natural products, there is still a lot of highly processed food on the market. Therefore, it seems reasonable to educate society on reasonable consumption. The aim of the study was to review the literature in terms of classification, mode of action and the impact of the most commonly used food additives on the health of children and adults. Unfortunately, eating habits of both adults and children differ significantly from the recommendations presented in the healthy eating pyramid. Food additives constitute an important element of the manufacturing process, which raises much controversy. These substances may accumulate in the organism and have a negative impact on health. The present literature review indicates the necessity of taking preventive measures and promoting education in terms of proper nutrition as well as the threats resulting from the consumption of highly processed food. 